\title{
Immunotherapy and targeted therapies in treatment of visceral leishmaniasis: current status and future prospects
}

\section{Om Prakash Singh and Shyam Sundar*}

Infectious Disease Research Laboratory, Department of Medicine, Institute of Medical Sciences, Banaras Hindu University, Varanasi, Uttar Pradesh, India

\section{Edited by:}

Nahid Ali, Indian Institute of Chemical Biology, India

\section{Reviewed by:}

Scott D. Gray-Owen, University of Toronto, Canada

Lynn Soong, The University of Texas

Medical Branch, USA

\section{*Correspondence:}

Shyam Sundar, Infectious Disease Research Laboratory, Department of Medicine, Institute of Medical Sciences, Banaras Hindu University, Varanasi, Uttar Pradesh 221005, India e-mail:drshyamsundar@hotmail.com
Visceral leishmaniasis (VL) is a vector-borne chronic infectious disease caused by the protozoan parasite Leishmania donovani or Leishmania infantum. VL is a serious public health problem, causing high morbidity and mortality in the developing world with an estimated 0.2-0.4 million new cases each year. In the absence of a vaccine, chemotherapy remains the favored option for disease control, but is limited by a narrow therapeutic index, significant toxicities, and frequently acquired resistance. Improved understanding of VL pathogenesis offers the development and deployment of immune based treatment options either alone or in combination with chemotherapy. Modulations of host immune response include the inhibition of molecular pathways that are crucial for parasite growth and maintenance; and stimulation of host effectors immune responses that restore the impaired effector functions. In this review, we highlight the challenges in treatment of VL with a particular emphasis on immunotherapy and targeted therapies to improve clinical outcomes.

Keywords: immunotherapy, visceral leishmaniasis, treatment, resistance, IL-10, anti-IL-10 mAb

\section{INTRODUCTION}

Leishmaniasis, a spectrum of diseases caused by Leishmania species, affects $\sim 12$ million people around the world, mostly in developing countries. It is transmitted by sand flies (Phlebotomus species) as extracellular flagellated promastigotes and replicate as intracellular, aflagellated amastigotes in mononuclear phagocytes in mammalian host (1). Depending on the species, the disease symptoms may range from self-healing skin lesions to the fatal visceral form known as kala-azar or visceral leishmaniasis (VL). Kala-azar is the most severe form of the leishmaniasis and accounts for 200-400 thousands new cases and over 50,000 deaths annually (2). Anthroponotic transmission of VL is caused by Leishmania donovani and prevails in Indian subcontinent and East Africa; while zoonotic transmission of VL is caused by $L$. infantum (syn. $L$. chagasi) in the Mediterranean region, South America, and Southwest and Central Asia. The majority of all cases (90\%) are found in India, Nepal, Bangladesh, Brazil, South Sudan, and Ethiopia (3), where transmission typically occurs from humans infected with kala-azar or post kala-azar dermal leishmaniasis (PKDL) (4, 5). More specifically, an estimated $80 \%$ of the global burden of VL occurs in South Asia (e.g. in 2007, 100,000-150,000 of the cases occurred in India alone). The situation is especially severe in Bihar State in eastern India, where some districts have faced the worst epidemic since the 1970s. Left untreated, VL is fatal, and the burden of disease expressed in disability-adjusted life years is estimated to be $\sim 2.5$ million. Furthermore, over $90 \%$ of all individuals with VL earn an income of $<2$ United States (US) dollars per day. Because VL is associated with resource-poor regions, access to care is another challenge in the overall management and treatment of $\operatorname{VL}(6,7)$. The situation is further complicated by the emergence of resistant strains to currently available anti-leishmanial drugs and by the limited availability of inexpensive, non-toxic drugs (Table 1). Antimonial chemotherapy has been the mainstay for
$\mathrm{VL}$ treatment for more than 50 years, and continues to be the recommended first line treatment in most parts of the world (8). Resistance to pentavalent antimonials $\left(\mathrm{Sb}^{\mathrm{v}}\right)$ has first been reported in northern Bihar, where nearly $60 \%$ of individuals are now unresponsive to this drug (9). Pentamidine has been the second line drug used in $\mathrm{Sb}^{\mathrm{v}}$ refractory patients. Unfortunately, its efficacy has also declined over the years, and now curing only $\sim 70 \%$ patients. Resistance has also been reported with pentamidine and miltefosine $(10,11)$, and there is growing concern for resistance with paromomycin monotherapy (12). Increasing parasite drug resistance, longer treatment times, and associated toxicity to patients has resulted in the need to use more expensive drugs such as AmBisome $^{\circledR}$ (liposomal amphotericin B) and miltefosine (8). A recent study demonstrated a single dose of liposomal amphotericin B is an effective VL treatment (13). However, concerns about emerging drug resistance with single drug therapy have led to testing liposomal amphotericin B in combination with oral miltefosine $(14,15)$. This strategy is still requiring administration of the drugs over an extended period and cost and toxic side effects are major issues. Hence, dose-sparing strategies that shorten treatment times are likely to be of major benefit to VL treatment programs. In addition, an intervention that can reduce the risk of developing PKDL is also highly desired. Importantly and relevant to this discussion, drug therapy works most effectively with help from the host immune system, and in particular, cell mediated immune (CMI) responses. Hence, immune modulation that stimulates immunity and work synergistically with drugs has enormous potential for drug-sparing strategies that would help in the treatment of a broad range of diseases.

Currently, there is no effective human vaccine available for any form of leishmaniasis. One of the major challenges in vaccine development has been a limited understanding of the precise immune mechanisms required for controlling parasite growth 
Table 1 | Current VL treatments with anti-leishmanial drugs: their mode(s) of action on parasites, dosage, efficacy, advantages and limitations.

\begin{tabular}{|c|c|c|c|c|c|c|c|}
\hline & Drugs & Mode(s) of action & Dosage & Efficacy (\%) & Advantages & Limitations & Reference \\
\hline 1 & $\begin{array}{l}\text { Pentavalent } \\
\text { antimonials: } \\
\text { sodium } \\
\text { stibogluconate } \\
\text { (Pentostam) or } \\
\text { meglumine } \\
\text { antimoniate } \\
\text { (Glucantime) }\end{array}$ & $\begin{array}{l}\text { Acts as pro-drug that is } \\
\text { converted to active and more } \\
\text { toxic trivalent form within the } \\
\text { amastigote/macrophage; and } \\
\text { this active trivalent Sblll form } \\
\text { inhibits trypanothione } \\
\text { reductase and exposes } \\
\text { parasite to oxidative stress of } \\
\text { the host }\end{array}$ & $\begin{array}{l}20 \mathrm{mg} / \mathrm{kg} / \text { day } \\
\text { (i.m.) for } \\
20-30 \text { days in } \\
\text { India }\end{array}$ & $\begin{array}{l}80-90(50 \% \text { in } \\
\text { Bihar, India) }\end{array}$ & $\begin{array}{l}\text { Low cost and } \\
\text { easily availability } \\
\text { in endemic area }\end{array}$ & $\begin{array}{l}\text { Pancreatitis, cardiac } \\
\text { arrhythmias, } \\
\text { acquired resistance } \\
\text { in the Indian } \\
\text { subcontinent }\end{array}$ & $(8,16,17)$ \\
\hline 2 & $\begin{array}{l}\text { Amphotericin B } \\
\text { (Fungizone) }\end{array}$ & $\begin{array}{l}\text { Form complexes and bind to } \\
\text { ergosterol in parasite } \\
\text { membranes that create } \\
\text { pores, which alter ion } \\
\text { balance, increase membrane } \\
\text { permeability resulting in cell } \\
\text { death; also acts as an inhibitor } \\
\text { of ergosterol biosynthesis }\end{array}$ & $\begin{array}{l}0.75-1.0 \mathrm{mg} / \mathrm{kg} \\
\text { for } 15-20 \\
\text { infusions either } \\
\text { daily on alternate } \\
\text { days in India (i.v) }\end{array}$ & $>95 \%$ & $\begin{array}{l}\text { Effective in } \\
\text { antimony } \\
\text { resistant regions, } \\
\text { primary } \\
\text { resistance is } \\
\text { unknown }\end{array}$ & $\begin{array}{l}\text { High cost and need } \\
\text { of prolonged } \\
\text { hospitalization, rigor, } \\
\text { and fever with renal } \\
\text { complications, } \\
\text { hypokalemia }\end{array}$ & $(16,18,19)$ \\
\hline 3 & $\begin{array}{l}\text { Liposomal } \\
\text { amphotericin B } \\
\text { (AmBisome) }\end{array}$ & $\begin{array}{l}\text { Targeted delivery of drug to } \\
\text { the infected macrophage and } \\
\text { mechanism of action is same } \\
\text { as amphotericin }\end{array}$ & $\begin{array}{l}3.0 \mathrm{mg} / \mathrm{kg} / \text { day for } \\
5 \text { days (total } \\
15 \mathrm{mg} \text { ) OR } \\
10 \mathrm{mg} / \mathrm{kg} \text { as a } \\
\text { single dose, i.v }\end{array}$ & $>96 \%$ & $\begin{array}{l}\text { Highly effective, } \\
\text { low toxicity, } \\
\text { resistance is not } \\
\text { documented }\end{array}$ & High cost & (13) \\
\hline 4 & $\begin{array}{l}\text { Paromomycin } \\
\text { (aminoglycoside } \\
\text { antibiotic), also } \\
\text { known as } \\
\text { aminosidine }\end{array}$ & $\begin{array}{l}\text { Exact mechanism is not } \\
\text { known. In bacteria, inhibits } \\
\text { protein synthesis, but in } \\
\text { Leishmania, it decreases the } \\
\text { mitochondrial membrane } \\
\text { potential of } L \text {. donovani } \\
\text { promastigotes }\end{array}$ & $\begin{array}{l}11 \mathrm{mg} / \mathrm{kg} \text { of } \\
\text { base/day for } \\
21 \text { days (i.m.) }\end{array}$ & $95 \%$ & $\begin{array}{l}\text { Acts } \\
\text { synergistically } \\
\text { with antimonials, } \\
\text { effective, well } \\
\text { tolerated, and } \\
\text { cheapest drug for } \\
\text { VL }\end{array}$ & $\begin{array}{l}\text { Reversible } \\
\text { ototoxicity but no } \\
\text { nephrotoxicity, lack } \\
\text { of efficacy in East } \\
\text { Africa }\end{array}$ & $(20-22)$ \\
\hline 5 & Miltefosine & $\begin{array}{l}\text { Interacts with the cell } \\
\text { membrane of Leishmania } \\
\text { parasites by modulation of } \\
\text { cell surface receptors, inositol } \\
\text { metabolism, and } \\
\text { phospholipase activation, Cell } \\
\text { death being mediated by } \\
\text { apoptosis }\end{array}$ & $\begin{array}{l}50 \mathrm{mg} / \text { day for } \\
\text { adults <25 kg and } \\
100 \mathrm{mg} / \text { day } \\
>50 \mathrm{~kg} \text { adults } \\
\text { (oral) }\end{array}$ & $85-95 \%$ & $\begin{array}{l}\text { First oral drug for } \\
\text { VL. Currently first } \\
\text { line of treatment } \\
\text { in Indian } \\
\text { subcontinent }\end{array}$ & $\begin{array}{l}\text { Potentially } \\
\text { teratogenic, } \\
\text { vomiting, and } \\
\text { diarrhea with } \\
\text { occasional hepatic } \\
\text { and renal toxicity }\end{array}$ & $(15,19)$ \\
\hline 6 & Pentamidine & $\begin{array}{l}\text { Accumulate in parasite } \\
\text { mitochondria and inhibit } \\
\text { mitochondrial topoisomerase } \\
\text { II, binding to AT-rich sites in } \\
\text { the minor groove of DNA } \\
\text { followed by inhibition of } \\
\text { transcription process }\end{array}$ & $\begin{array}{l}4 \mathrm{mg} / \mathrm{kg} / \text { day for } \\
\text { three times } \\
\text { weekly for } 15-20 \\
\text { dose (i.m or i.v) }\end{array}$ & $70-80 \%$ & $\begin{array}{l}\text { Low efficacy, } \\
\text { toxic. May be } \\
\text { used in } \\
\text { combination with } \\
\text { other drugs }\end{array}$ & $\begin{array}{l}\text { Gastrointestinal side } \\
\text { effects, cardiac, } \\
\text { arrhythmias, } \\
\text { hypotension, } \\
\text { pancreatitis, and } \\
\text { irreversible } \\
\text { insulin-dependent } \\
\text { diabetes mellitus }\end{array}$ & $(23,24)$ \\
\hline
\end{tabular}

$(25,26)$. In the present review, we highlight the current status and challenges in treatment of leishmaniasis with focus on immune based strategy for improving treatment regimens for VL.
IMMUNE REGULATION AND IMMUNOPATHOGENESIS

Mammals have evolved to recognize and control pathogens, including the recognition of infected cells. This is achieved by the coordinated actions of innate and adaptive immune mechanisms 
[reviewed in Ref. (27)]. The innate immune response involves the recognition and early control of threats to the body as well as for the activation of adaptive immunity. Adaptive immune response involves $\mathrm{B}$ cells that produce specific antibodies; and $\mathrm{T}$ cells that recognize peptide antigens. $T$ cell responses are mediated by $\mathrm{CD}^{+} \mathrm{T}$ cells that recognize peptides derived from both inside and outside of cells and presented by major histocompatibility class (MHC) I molecules on the cell surface or $\mathrm{CD}^{+}{ }^{+} \mathrm{T}$ cells that recognize peptides from microbes or antigens engulfed by professional phagocytes and then presented on the context of MHC II molecules. The main targets of immunomodulatory strategies should be $\mathrm{CD}^{+} \mathrm{T}$ cells because they play critical roles in coordinating immune responses by producing molecules critical for the production of high affinity antibodies by B cells, essential for activation of $\mathrm{CD}^{+} \mathrm{T}$ cells to kill infected and transformed cells.

Based on the studies in the L. major/BALB/c mouse model, the immune dysregulation associated with non-healing and disseminating forms of leishmaniasis has been associated with a parasite-driven Th2 polarized response, in which interleukin (IL)4 is especially dominant [reviewed in Ref. (28)]. Accumulating data in human VL, however, indicate that the cytokine responses are not highly polarized, and even during the acute phase of disease, elevated levels of interferon- $\gamma($ IFN- $\gamma)$ mRNA have been found in lesional tissue, such as the spleen and bone marrow (29-31). Furthermore, in human VL, overproduction of IL-10 provides a much better correlate of susceptibility than IL-4. The vast array of cytokines, chemokines, and immune mechanisms involved in the host immune response to Leishmania clearly highlights the complexity of diseases $(32,33)$. Based on studies in mice, production of interleukin-12 (IL-12) by antigen-presenting cells (APCs) and IFN- $\gamma$ by T cells appear to be required for the control of the parasites and development of acquired resistance $(34,35)$. IL-12 is regulatory cytokine for initiation and maintenance of the Th1 response and plays an important role in the induction of IFN$\gamma$ production by $\mathrm{T}$ and NK cells (36-40). Priming of susceptible BALB/c mice with exogenous rIL-12 during Leishmania infection also promotes protection and gives self-healing phenotype (41, 42). On the other hand, Leishmania parasites have been shown to inhibit IL-12 production, resulting in decreased leishmanicidal activity of macrophage (43). Maintenance of the proportion of $\mathrm{CD}^{+}$and $\mathrm{CD}^{+} \mathrm{T}$ cells required for cytokines secretion is the crucial step in generation of immunity against leishmaniasis. In active VL, both CD4 and CD8 cells are activated and play distinct but cooperative role in disease resolution. $\mathrm{CD}^{+}$cells play a role in the control of primary infection, while $\mathrm{CD}^{+}$cells are thought to be more important during secondary immune response (44).

Human VL is characterized by very high titers of Leishmaniaspecific antibodies, appearing soon after infection but before the development of cellular immunological abnormalities $(45,46)$. These anti-leishmanial antibodies persist up to 16 years after treatment, suggesting its possible involvement in immunity (47). There are reports that B cells and antibodies correlate with pathology, but role of these antibodies in disease resolution or protection is unknown. Studies have also shown that animals lacking B cells are resistant to Leishmania infections (48), but such evidence on human VL are still lacking. Importantly, in endemic area of Bihar (India), strong association were found between seropositivity and progression to clinical diseases in healthy individual (49), suggesting its role in disease pathogenesis. Therefore, in-depth studies are required before any conclusion can be drawn. More recently, we have reported high anti-leishmanial antibodies in Indian VL patients compared to Sudanese patients and could be one of the factor for lower sensitivity of serological tests in East Africa (50). Most importantly, anti-leishmanial antibodies do not play any role in antigen-specific IFN- $\gamma$ or IL-10 production in whole blood of active VL patients (unpublished data).

\section{TARGETED THERAPY AND IMMUNOTHERAPY}

In the absence of human vaccine and effective vector control measures, chemotherapy is the only option for treatment and control of VL. Several hundred comparative and prospective cohort studies on therapies for leishmaniasis have been published (Table 1). Increasing evidence of drug unresponsiveness and resistance has raised concern to save the drugs, as the armory of anti-leishmanial drugs is limited. Reports of emerging resistance to Miltefosine, the newest and only oral anti-leishmanial drugs, which is the basis of VL elimination program, are particularly worrying (14); and makes VL management and elimination challenging. Drug discovery is struggling to prevent resistance, therefore changes in the drug policy are much needed step as on today. Reductions in VL morbidity and mortality will require the development and deployment of immune modulators in order to achieve the prophylactic or therapeutic goal; and also prevent the transmission of Leishmania from human to sand fly. One of the most interesting approaches currently being explored is immunotherapy and targeted therapy [reviewed in Ref. (51)]. Targeted therapies act by blocking essential biochemical or signaling pathways that are indispensable for Leishmania parasite growth and survival, however, immunotherapy involves the use of biological molecules or compounds to modulate immune responses in combination with drugs. Over the last two decades, various approaches of immunotherapies or targeted therapies have been developed and applied in the treatment of human leishmaniasis (Table 2). The strengths and weaknesses of such therapies suggest that both approaches might have complimentary roles in VL treatment, and combination could prove synergistic. Because targeted therapies can induce rapid parasite clearance, with a consequent decrease in Leishmania associated immune-suppression, they might afford a favorable window for immunotherapy to improve the efficacy of treatment.

\section{TARGETING HOST IMMUNITY BY ANTI-LEISHMANIAL DRUGS/MOLECULES}

Within the mammalian host, parasites reside as amastigotes in phagocytic cells such as polymorphonuclear neutrophils (PMN), macrophages, and dendritic cells (DCs). Therefore, it is important to identify an immunomodulatory compound with leishmanicidal properties capable of activating phagocytic cells. Following entry of Leishmania parasite into the mammalian host, PMNs are thought to be the first effector cells recruited to the site of infection within $24 \mathrm{~h}$, implying that they possibly serve as host cells for Leishmania parasites in the very early phase of infection (67). Neutrophils being inherently short-lived and apoptotic, are usually cleared without triggering activation of macrophages (67), while Leishmania parasites are known to delay neutrophils apoptosis, 
Table 2 | Immunotherapy of human leishmaniasis

\begin{tabular}{|c|c|c|c|c|c|c|c|}
\hline Country & Year & Immunotherapeutic agent & $\begin{array}{c}\text { Chemotherapeutic } \\
\text { agent }\end{array}$ & $\begin{array}{c}\text { No. of } \\
\text { patients }\end{array}$ & $\begin{array}{l}\text { Disease/ } \\
\text { parasite }\end{array}$ & $\begin{array}{c}\text { Treatment } \\
\text { efficacy }\end{array}$ & Reference \\
\hline India & 1995 & IFN- $\gamma$ & $\mathrm{Sb}^{v}$ & 16 & $\mathrm{VL}$ & $87 \%$ & $(52)$ \\
\hline Brazil & 1990 & IFN- $\gamma$ & $\mathrm{Sb}^{v}$ & 17 & $\mathrm{VL}$ & $82.3 \%$ & (53) \\
\hline Brazil & 2005 & GM-CSF & $\mathrm{Sb}^{v}$ & 05 & $\mathrm{CL}$ & $100 \%$ Cure & $(54)$ \\
\hline Brazil & 2006 & Killed L. amazonensis + BCG & Glucantime & 47 & $\mathrm{ACL}$ & $87 \%$ & $(55)$ \\
\hline Brazil & 2006 & Mixed antigens ${ }^{a}$ & - & 06 & $\mathrm{MCL}$ & $76-94 \%$ & $(56)$ \\
\hline Brazil & 2002 & Killed L. amazonensis & Meglumine & 47 & $\mathrm{ACL}$ & $100 \%$ & $(57)$ \\
\hline Argentina & 2011 & Killed L. amazonensis + BCG & - & 01 & $\mathrm{ACL}$ & High & $(58)$ \\
\hline Peru & 2007 & Imiquimod & $\mathrm{Sb}^{\mathrm{V}}$ & 07 & $\mathrm{CL}$ & $72 \%$ & $(59)$ \\
\hline Kenya & 1993 & IFN- $\gamma$ & $\mathrm{Sb}^{v}$ & 10 & VL & $75 \%$ & $(60)$ \\
\hline Sudan & 2008 & Alum/ALM + BCG & $\mathrm{Sb}^{\vee}$ & 15 & PKDL & $87 \%$ & $(61)$ \\
\hline Iran & 2006 & Imiquimod & Glucantime & 59 & $\mathrm{CL}$ & $44.1 \%$ & $(62)$ \\
\hline Uzbekistan & 1993 & Leukinferon (i.m.) & Monomycin & 50 & $\mathrm{CL}$ & High & (63) \\
\hline Venezuela & 1990-1999 & Pasteurized L. braziliensis + BCG & - & 5341 & $\mathrm{CL}$ & $91.2-98.7 \%$ & $(64)$ \\
\hline Venezuela & 1994-2000 & Mixture antigens ${ }^{b}$ & $\mathrm{Sb}^{v}$ & 87 & $\mathrm{CL}$ & Moderate & $(65)$ \\
\hline Venezuela & 2004 & Pasteurized L. braziliensis + BCG & - & 07 & MCL, DCL & $100 \%$ & $(66)$ \\
\hline
\end{tabular}

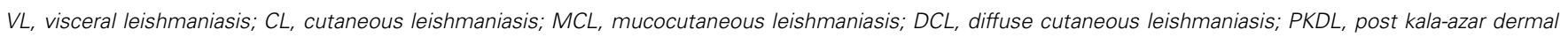
leishmaniasis; BCG, bacillus Calmette-Guerin; Sb, sodium stiboguconate; IFN- $\gamma$, interferon- $\gamma$; mixture antigens

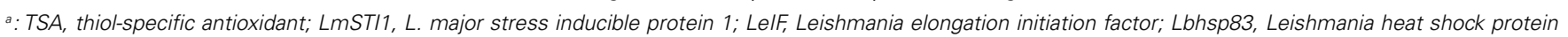
83; GM-CSF, granulocyte macrophage colony-stimulating factor; mixture antigens

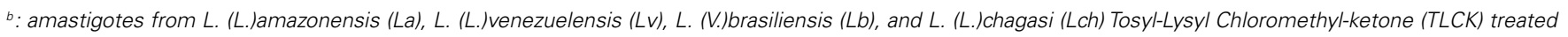
and Non-idet P-40(NP-40) extracted (VT).

possibly by interfering with production of reactive oxygen species (ROS) $(68,69)$. Therefore, it would be logical and important to search an anti-leishmanial compound capable of generating an oxidative burst within Leishmania infected neutrophils to effectively eliminate parasites. Berberine chloride has been one of the compounds recently reported to enhance the apoptosis of $L$. donovani-infected neutrophils via modulation of the MAP kinase pathways (70).

Leishmania parasites that enter into macrophages via the uptake of infected, apoptotic PMNs may survive and multiply effectively (67). Since, macrophages have ability to kill parasite upon activation, Leishmania parasites overcome these macrophage activation and recognition by creating an anti-inflammatory milieu, beneficial for parasites survival. It has been reported that the amount of TGF- $\beta$ secreted by macrophages following uptake of infected PMNs is higher than after direct uptake of $L$. major promastigotes (67), suggests that uptake of infected, apoptotic PMNs are responsible for creation of this environment within macrophages. Therefore, targeting pathogens residing in neutrophils should be taken into consideration when designing targeted novel antileishmanial compounds, as neutrophils harbor and transport parasites. For example, antimonials (sodium stibogluconate) increase the phagocytic capacity of neutrophils along with increased production of superoxide (71), unfortunately the loss of efficacy of antimonials has occurred in the Indian subcontinent and thus raised concern to search another compounds. In fact, several strategies to interfere with macrophage signaling by parasites have been reported that favor its survival in host cells (72). Oghumu et al. have highlighted the role of STAT4 pathway in immunity to $L$. donovani infection and also reported the evidence that
STAT4 is dispensable for antimonial-based chemotherapy (73). Furthermore, some of the other strategies employed by Leishmania to evade effector mechanisms of the host immune system are the recruitment of inhibitory $\mathrm{CD} 4{ }^{+} \mathrm{CD} 25^{+}$FoxP3 ${ }^{+}$regulatory $\mathrm{T}$ cells (Treg) $(74,75)$, inhibition of macrophage phagosomal maturation (76), and inhibition of DC maturation (77). Receptors expressed on Treg or its corresponding ligands on effectors cells, such as glucocorticoid-induced TNF receptor family-related protein (GITR), PD-1, it is ligands programed cell death ligand-1 (PD-L1, B7-H1) or cytotoxic T lymphocyte antigen-4 (CTLA-4) could be also used as potential targets in future studies, as targeting these regulatory pathways has proven effective in experimental VL $(78,79)$.

\section{CYTOKINE IMMUNOTHERAPY}

Cytokines are the messengers of the immune system. They have autocrine and paracrine functions, so that they function locally or at a distance to suppress or enhance immunity. Attempts to identify cytokines that selectively induce Th1 responses might be useful in VL therapy. The evidence of the utility of cytokines as therapeutic use came from the studies by Murray et al., when an anti-IL-10 receptor monoclonal antibody (anti-IL-10R mAb) was reported to inflict parasite killing through an inducible nitric oxide synthase-dependent mechanism (80). Thus, immunostimulatory cytokines (e.g., IFN- $\gamma$, IL-12, GM-CSF) or antibodies that target suppressive/deactivating cytokines are being investigated or proposed as monotherapies or as combination therapies with $\mathrm{Sb}^{\mathrm{v}}$ or other drugs. Combination therapy with recombinant human IFN- $\gamma$ and pentavalent antimonials have been reported as stronger parasitological and clinical cure; compared with the drug alone in 
VL patients from Brazil, Kenya, and India (53, 60, 81). Short course of IFN- $\gamma$ is thought to be sufficient to activate macrophage and thereby accelerate parasitologic effect of $\mathrm{Sb}^{\mathrm{v}}$. IL-12 is another key cytokine inhibited by Leishmania parasites. Exogenous treatment with rIL-12 during Leishmania infection leads to resistance in susceptible mice (41), suggesting its important use in clinical outcome. However, suppression of other cytokines, including receptor fusion antagonists of IL-13, IL-4, and TGF- $\beta$ inhibit parasite replication but only marginally affect parasite clearance without the induction of a synergistic effect with pentavalent antimonials (82). In a study, GM-CSF plus either with meglumine antimonite (54) or a mixture of L. major antigens (LmSTI1 + LeIf + HSP83) (56), was reported as being highly effective in treating American CL and MCL (Table 2).

\section{IL-10: ROLE IN VL PATHOGENESIS AND IMMUNOTHERAPY}

Visceral leishmaniasis pathogenesis has been associated to an overproduction of the regulatory cytokine, IL-10, which can promote parasite replication and disease progression. Several studies performed to characterize the immunologic effects of VL have focused on the role of IL-10 in the suppression of DC functions and rendering macrophages unresponsive to activation signals (83). Experimental models have demonstrated that IL-10 plays a central role in the pathogenesis and parasite growth in VL, as IL-10-deficient $\mathrm{BALB} / \mathrm{c}$ and C57BL6 mice are highly resistant to L. donovani infection (84). Treatment of $L$. donovani-infected wild-type mice with a single dose anti-IL-10R mAb and daily low doses of $\mathrm{Sb}^{\mathrm{v}}$ resulted in rapid control of the $L$. donovani infection and dramatically enhanced the therapeutic effects of $\mathrm{Sb}^{\mathrm{v}}$ namely, an over 10 -fold dose-sparing effect was observed with $\mathrm{Sb}^{\mathrm{v}}$ and a shortened duration of treatment (85). In a separate study, single dose anti-IL-10R $\mathrm{mAb}(0.5 \mathrm{mg})$ treatment triggered a $63 \%$ liver parasite killing in $L$. donovani-infected BALB/c mice; moreover, when administered at a reduced dose $(0.1 \mathrm{mg})$, the anti-IL- $10 \mathrm{mAb}$ enhanced the effect of $\mathrm{Sb}^{\mathrm{v}}$, also administered at a suboptimal dose $(50 \mathrm{mg} / \mathrm{kg})$, leading to a $72 \%$ liver parasite killing (82). Similar results were observed in $L$. donovani-infected $\mathrm{BALB} / \mathrm{c}$ mice treated with a suboptimal single dose $(0.1 \mathrm{mg})$ of an anti-IL-10R mAb and low-dose Amphotericin B ( $2 \mathrm{mg} / \mathrm{kg}$ total dose) (86). The combination therapy induced a $76 \%$ liver parasite killing, compared with a $16 \%$ observed with the anti-IL-10R mAb alone.

Elevated levels of IL-10 in serum as well as enhanced IL-10 mRNA expression in lesional tissue during active disease are a consistent finding in human VL [reviewed in Ref. (87)]. More recently, we have reported antigen stimulated IL-10 production in whole blood cells of VL patients and have shown a strong association of IL-27 and IL-21 with the up-regulation of the IL-10 response, and revealed the presence of both IFN- $\gamma$ and IL-10 producing antigen-specific cells in the peripheral blood of VL patients $(74,88,89)$. The findings have led to an underlying hypothesis that during active disease antigen-specific IL-10 producing $\mathrm{T}$ cells are activated under conditions that also drive strong and persistent Th1 responses, and the balance of these cells and the cytokines they produce favors the progression of disease. It has been shown that infected macrophages, Th1, Th2, $\mathrm{CD}^{+} \mathrm{T}$ cells, and subsets Treg, of which naturally occurring $\mathrm{CD} 4{ }^{+} \mathrm{CD} 25^{+}$Foxp $^{+}{ }^{+}$Treg cells and antigen-inducible or adaptive Treg are the best defined, are all a potential source of IL-10 capable of suppressing Leishmania-specific immunity (90-92). Key findings have identified $\mathrm{CD} 4^{+} \mathrm{CD} 25^{-}$Foxp $3^{-}$or adaptive Treg as the main source of both elevated IL-10 and IFN- $\gamma$ in the spleen of VL patients (74). Furthermore, antigen driven IL-10 production has been difficult to detect in culture of peripheral blood mononuclear cells (PBMCs) $(88,93,94)$. These findings are consistent with reports from a number of studies, which suggest that the immunologic defect in VL is characterized not by the complete absence of a potentially curative type 1 immune response, but by the co-expression of suppressive cytokines that compromise the leishmanicidal function and potency of the effector response in target organs, such as the spleen. A direct role for IL-10 in the pathology of VL is supported by studies demonstrating that IL-10 blockade can enhance IFN- $\gamma$ responses $(29,95)$. More recently, we have demonstrated anti-parasitic effect of IL-10 blockade in human VL, showing that neutralization of IL-10 results in marked reduction of parasite number present in splenic aspirate cells (89). In continuation with these ex vivo supporting findings, Phase I study of anti-IL-10 mAb alone and in combination with AmBisome have been recently proposed for the human trial (clinicaltrial.gov) and this combination is expected to induce synergistic effects that contain the VL infection and immunopathology associated with the disease, while overcoming the threat of drug resistance and possibly achieving a chemotherapeutic dose-sparing effect that results in better efficacy and adherence to treatment. Importantly, demonstrating a therapeutic benefit from the IL-10 neutralization as a proof of concept will open the door to other strategies targeting the inhibition of IL-10 and other immunosuppressive factors.

\section{DENDRITIC CELL-BASED IMMUNOTHERAPY}

Another novel approach is the application of DCs for the induction of antigen-specific T cell immunity. The interaction of DCs and Leishmania parasites are complex and thought to be responsible for control of infection or progression of clinical disease (96). DCs play an important role in initial anti-Leishmania $\mathrm{T}$ cell responses and promoting their differentiation into memory $\mathrm{T}$ cell to achieve long lasting immunity, which makes them attractive candidates for potential synergy with immunotherapy [reviewed in Ref. (51)]. Interestingly, a C-type lectin receptor, DC-SIGN (DC-specific ICAM-3-grabbing non-integrin), which is exclusively expressed on tissue monocyte-derived DCs, has been shown to favor parasite survival by binding with distinct Leishmania species. It is then suggested that this receptor could also be taken into consideration as therapeutic target for both visceral and cutaneous leishmaniasis (97).

Dendritic cells based immunotherapy combined with antimony-based chemotherapy has been shown very effective against murine VL (98). Bone marrow derived DCs pulsed with soluble $L$. donovani antigen when given in combination with antimonials has been shown to reduce both hepatic and splenic parasite burden significantly (51). Thus, the future of DC-based immunotherapy appears promising and it could be looked upon as a prospective vaccine against VL.

\section{CHALLENGES AND FUTURE DIRECTIONS}

Treatments that enhance immune responses to fight against diseases are of significant clinical interest. A possible approach to overcome some of the challenges associated with the management 
and treatment of VL is the use of immune based combination therapy (99), which has been proven successful in other parasitic diseases, such as malaria, tuberculosis, and leprosy (100). A combination of drugs with different modes of action could eliminate the potential for drug resistance and induce a chemotherapeutic dose-sparing effect, since the mechanism for resistance would be different for each drug (100). One drug could target the parasite itself, while a second drug or compound could modulate the immune system of the host (101-103). Likewise, the combination of drugs with different half-lives could provide a synergistic effect in the timing and exposure of the parasite to the different drug levels $(100,103)$.

Although, considerable progress on VL treatment has been made over the past years, we still have a limited understanding of the precise immune mechanism underlying human VL. One of the major problems in translating discoveries from disease models into treatments for humans is the risk that potential treatment strategies do not work on human cells in the same way as they do in the experimental model. Second and most important key issue for immunotherapy or targeted therapies is whether intensified anti-Leishmanial effects can be achieved without a corresponding increase in serious toxicities, as immunomodulatory agents that provoke an immune response may also pose a risk of severe sensitization, which might be anticipated to increase allergic reactions and lead to reduction in treatment efficacy.

Cytokine (e.g., IL-10) has therapeutically been used as a recombinant protein (i.e., a large molecule), which is quite expensive to produce. It can be only administered by injection, which is also quite inconvenient for the patient. It will then be important to ensure that the cost associated with cytokine immunotherapy must be less than conventional treatment and reach to the populations that need it most. Another better approaches could be to target the molecules acting downstream of the cytokine receptors or signal transduction. The problems in such cases are the specificity, as the known cytokine signaling pathways are shared by different cytokines. Therefore, problems and side effects associated with the use of cytokine therapy have to be addressed properly before its clinical application.

Although, these observations strongly support immunotherapy as a promising alternative to conventional chemotherapy against $\mathrm{VL}$, big challenge remains to ensure long term maintenance of response and safety of treatments with biologic agents.

\section{CONCLUSION}

Each VL patients represents our failure to prevent leishmaniasis, and each death represents our failure to treat soon enough. Until VL elimination has been achieved, drug treatment will remain crucial to prevent complications and death from VL. There is an urgent need for innovative and effective alternative therapies against VL. Understanding of crucial cellular pathways that promote Leishmania parasite growth and maintenance together with the development of compounds or agents that specifically inhibit these pathways has offered a new era for anti-leishmanial therapy. The use of immunotherapy and targeted therapy could aid in addressing some of the current challenges associated with the management and treatment of VL, namely, minimizing resistance to currently available drugs, improving the therapeutic index, decreasing the dose or length of treatment, and reducing the cost of therapy. With the emergence of targeted delivery systems and technology to block the IL-10 transcription and other relevant molecules involved in the IL-10 signaling (e.g., STAT3), a new era of molecular targeting of regulatory cytokines is on the horizon.

\section{ACKNOWLEDGMENTS}

This work was supported by Extramural Program of the National Institute of Allergy and Infectious Diseases (NIAID), National Institute of Health (TMRC Grant No. P50AI074321). Authors thank Ms. Neetu Singh and Mr. Shashi Bhushan, Research Scholar of Department of Medicine, Banaras Hindu University for helpful comments and suggestions in the preparation of the manuscript. Om Prakash Singh thanks CSIR, New Delhi for providing Senior Research Fellowship.

\section{REFERENCES}

1. Desjeux P. Leishmaniasis. Public health aspects and control. Clin Dermatol (1996) 14:417-23. doi:10.1016/0738-081X(96)00057-0

2. World Health Organization. Eliminating Visceral Leishmaniasis: A MultiPronged Approach. Available at: http://www.who.int/tdr/news/2011/ vl-elimination/en/

3. Alvar J, Velez ID, Bern C, Herrero M, Desjeux P, Cano J, et al. Leishmaniasis worldwide and global estimates of its incidence. PLoS One (2012) 7:e35671. doi:10.1371/journal.pone.0035671

4. Addy M, Nandy A. Ten years of kala-azar in West Bengal, part I. Did post-kalaazar dermal leishmaniasis initiate the outbreak in 24-parganas? Bull World Health Organ (1992) 70:341-6.

5. Bern C, Hightower AW, Chowdhury R, Ali M, Amann J, Wagatsuma Y, et al. Risk factors for kala-azar in Bangladesh. Emerg Infect Dis (2005) 11:655-62. doi:10.3201/eid1105.040718

6. Alvar J, Yactayo S, Bern C. Leishmaniasis and poverty. Trends Parasitol (2006) 22:552-7. doi:10.1016/j.pt.2006.09.004

7. Meheus F, Boelaert M, Baltussen R, Sundar S. Costs of patient management of visceral leishmaniasis in Muzaffarpur, Bihar, India. Trop Med Int Health (2006) 11:1715-24. doi:10.1111/j.1365-3156.2006.01732.x

8. Croft SL, Sundar S, Fairlamb AH. Drug resistance in leishmaniasis. Clin Microbiol Rev (2006) 19:111-26. doi:10.1128/CMR.19.1.111-126.2006

9. Sundar S, More DK, Singh MK, Singh VP, Sharma S, Makharia A, et al. Failure of pentavalent antimony in visceral leishmaniasis in India: report from the center of the Indian epidemic. Clin Infect Dis (2000) 31:1104-7. doi:10.1086/318121

10. Pandey BD, Pandey K, Kaneko O, Yanagi T, Hirayama K. Relapse of visceral leishmaniasis after miltefosine treatment in a Nepalese patient. Am J Trop Med Hyg (2009) 80:580-2.

11. Sundar S, Rai M. Treatment of visceral leishmaniasis. Expert Opin Pharmacother (2005) 6:2821-9. doi:10.1517/14656566.6.16.2821

12. Jha TK. Drug unresponsiveness \& combination therapy for kala-azar. Indian J Med Res (2006) 123:389-98.

13. Sundar S, Chakravarty J, Agarwal D, Rai M, Murray HW. Single-dose liposomal amphotericin B for visceral leishmaniasis in India. N Engl J Med (2010) 11:504-12. doi:10.1056/NEJMoa0903627

14. Sundar S, Singh A. What steps can be taken to counter the increasing failure of miltefosine to treat visceral leishmaniasis? Expert Rev Anti Infect Ther (2013) 11:117-9. doi:10.1586/eri.12.170

15. Sundar S, Singh A, Rai M, Prajapati VK, Singh AK, Ostyn B, et al. Efficacy of miltefosine in the treatment of visceral leishmaniasis in India after a decade of use. Clin Infect Dis (2012) 55:543-50. doi:10.1093/cid/cis474

16. Croft SL, Olliaro P. Leishmaniasis chemotherapy - challenges and opportunities. Clin Microbiol Infect (2011) 17:1478-83. doi:10.1111/j.1469-0691.2011. 03630.x

17. Singh N, Singh RT, Sundar S. Novel mechanism of drug resistance in kala azar field isolates. J Infect Dis (2003) 188:600-7. doi:10.1086/377133

18. Sundar S, Chakravarty J, Rai VK, Agrawal N, Singh SP, Chauhan V, et al. Amphotericin B treatment for Indian visceral leishmaniasis: response to 15 daily versus alternate-day infusions. Clin Infect Dis (2007) 45:556-61. doi:10.1086/520665 
19. Sundar S, Kumar K, Chakravarty J, Agrawal D, Agrawal S, Chhabra A, et al. Cure of antimony-unresponsive Indian post-kala-azar dermal leishmaniasis with oral miltefosine. Trans R Soc Trop Med Hyg (2006) 100:698-700. doi:10.1016/j.trstmh.2005.09.015

20. Jhingran A, Chawla B, Saxena S, Barrett MP, Madhubala R. Paromomycin: uptake and resistance in Leishmania donovani. Mol Biochem Parasitol (2009) 164:111-7. doi:10.1016/j.molbiopara.2008.12.007

21. Sundar S, Jha TK, Thakur CP, Sinha PK, Bhattacharya SK. Injectable paromomycin for visceral leishmaniasis in India. NEngl J Med (2007) 356:2571-81. doi:10.1056/NEJMoa066536

22. Sundar S, Chakravarty J. Paromomycin in the treatment of leishmaniasis. Expert Opin Investig Drugs (2008) 17:787-94. doi:10.1517/13543784.17.5.787

23. Das VN, Ranjan A, Sinha AN, Verma N, Lal CS, Gupta AK, et al. A randomized clinical trial of low dosage combination of pentamidine and allopurinol in the treatment of antimony unresponsive cases of visceral leishmaniasis. JAssoc Physicians India (2001) 49:609-13.

24. Das VN, Siddiqui NA, Pandey K, Singh VP, Topno RK, Singh D, et al. A controlled, randomized nonblinded clinical trial to assess the efficacy of amphotericin B deoxycholate as compared to pentamidine for the treatment of antimony unresponsive visceral leishmaniasis cases in Bihar, India. Ther Clin Risk Manag (2009) 5:117-24. doi:10.2147/TCRM.S3581

25. Das A, Ali N. Vaccine development against Leishmania donovani. Front Immunol (2012) 3:99. doi:10.3389/fimmu.2012.00099

26. Singh OP, Stober CB, Singh AK, Blackwell JM, Sundar S. Cytokine responses to novel antigens in an Indian population living in an area endemic for visceral leishmaniasis. PLoS Negl Trop Dis (2012) 6:e1874. doi:10.1371/journal.pntd. 0001874

27. Janeway CA, Medzhitov R. Innate immune recognition. Annu Rev Immunol (2002) 20:197-216. doi:10.1146/annurev.immunol.20.083001.084359

28. Sacks D, Noben-Trauth N. The immunology of susceptibility and resistance to Leishmania major in mice. Nat Rev Immunol (2002) 2:845-58. doi:10.1038/nri933

29. Ghalib HW, Piuvezam MR, Skeiky YA, Siddig M, Hashim FA, el-Hassan AM, et al. Interleukin 10 production correlates with pathology in human Leishmania donovani infections. J Clin Invest (1993) 92:324-9. doi:10.1172/JCI116570

30. Karp CL, el-Safi SH, Wynn TA, Satti MM, Kordofani AM, Hashim FA, et al. In vivo cytokine profiles in patients with kala-azar. Marked elevation of both interleukin-10 and interferon-gamma. J Clin Invest (1993) 91:1644-8. doi:10.1172/JCI116372

31. Kenney RT, Sacks DL, Gam AA, Murray HW, Sundar S. Splenic cytokine responses in Indian kala-azar before and after treatment. J Infect Dis (1998) 177:815-8. doi:10.1086/517817

32. Bhattacharya P, Ali N. Involvement and interactions of different immune cells and their cytokines in human visceral leishmaniasis. Rev Soc Bras Med Trop (2013) 46:128-34. doi:10.1590/0037-8682-0022-2012

33. Cummings HE, Tuladhar R, Satoskar A. Cytokines and their STATs in cutaneous and visceral leishmaniasis. J Biomed Biotechnol (2010) 2010:294389. doi:10.1155/2010/294389

34. Basu A, Chakrabarti G, Saha A, Bandyopadhyay S. Modulation of CD11C+ splenic dendritic cell functions in murine visceral leishmaniasis: correlation with parasite replication in the spleen. Immunology (2000) 99:305-13. doi:10.1046/j.1365-2567.2000.00939.x

35. Schwarz T, Remer KA, Nahrendorf W, Masic A, Siewe L, Müller W, et al. T cell-derived IL-10 determines leishmaniasis disease outcome and is suppressed by a dendritic cell based vaccine. PLoS Pathog (2013) 9:e1003476. doi:10.1371/journal.ppat.1003476

36. Bacellar O, Brodskyn C, Guerreiro J, Barral-Netto M, Costa CH, Coffman $\mathrm{RL}$, et al. Interleukin-12 restores interferon-gamma production and cytotoxic responses in visceral leishmaniasis. J Infect Dis (1996) 173:1515-8. doi:10.1093/infdis/173.6.1515

37. Ghalib HW, Whittle JA, Kubin M, Hashim FA, el-Hassan AM, Grabstein KH, et al. IL-12 enhances Th1-type responses in human Leishmania donovani infections. J Immunol (1995) 154:4623-9.

38. Kobayashi M, Fitz L, Ryan M, Hewick RM, Clark SC, Chan S, et al. Identification and purification of natural killer cell stimulatory factor (NKSF), a cytokine with multiple biologic effects on human lymphocytes. J Exp Med (1989) 170(3):827-45. doi:10.1084/jem.170.3.827
39. Scharton TM, Scott P. Natural killer cells are a source of interferon gamma that drives differentiation of CD4+ T cell subsets and induces early resistance to Leishmania major in mice. J Exp Med (1993) 178:567-77. doi:10.1084/jem. 178.2.567

40. Trinchieri G. Interleukin-12 and its role in the generation of TH1 cells. Immunol Today (1993) 14(7):335-8. doi:10.1016/0167-5699(93)90230-I

41. Heinzel FP, Schoenhaut DS, Rerko RM, Rosser LE, Gately MK. Recombinant interleukin 12 cures mice infected with Leishmania major. J Exp Med (1993) 177:1505-9. doi:10.1084/jem.177.5.1505

42. Murray HW, Hariprashad J, Coffman RL. Behavior of visceral Leishmania donovani in an experimentally induced T helper cell 2 (Th2)-associated response model. J Exp Med (1997) 185:867-74. doi:10.1084/jem.185.5.867

43. Ahuja SS, Reddick RL, Sato N, Montalbo E, Kostecki V, Zhao W, et al. Dendritic cell (DC)-based anti-infective strategies: DCs engineered to secrete IL-12 are a potent vaccine in a murine model of an intracellular infection. J Immunol (1999) 163:3890-7.

44. Alexander CE, Kaye PM, Engwerda CR. CD95 is required for the early control of parasite burden in the liver of Leishmania donovani-infected mice. Eur J Immunol (2001) 31:1199-210. doi:10.1002/1521-4141(200104)31:4<1199: :AID-IMMU1199>3.0.CO;2-6

45. De Almeida Silva L, Romero HD, Prata A, Costa RT, Nascimento E, Carvalho SF, et al. Immunologic tests in patients after clinical cure of visceral leishmaniasis. Am J Trop Med Hyg (2006) 75:739-43.

46. Hailu A. Pre- and post-treatment antibody levels in visceral leishmaniasis. Trans R Soc Trop Med Hyg (1990) 84:673-5. doi:10.1016/0035-9203(90) 90141-Z

47. Gidwani K, Picado A, Ostyn B, Singh SP, Kumar R, Khanal B, et al. Persistence of Leishmania donovani antibodies in past visceral leishmaniasis cases in India. Clin Vaccine Immunol (2010) 18:346-8. doi:10.1128/CVI.00473-10

48. Hoerauf A, Solbach W, Lohoff M, Rollinghoff M. The Xid defect determines an improved clinical course of murine leishmaniasis in susceptible mice. Int Immunol (1994) 6:1117-24. doi:10.1093/intimm/6.8.1117

49. Hasker E, Malaviya P, Gidwani K, Picado A, Ostyn B, Kansal S, et al. Strong association between serological status and probability of progression to clinical visceral leishmaniasis in prospective cohort studies in India and Nepal. PLoS Negl Trop Dis (2014) 8(1):e2657. doi:10.1371/journal.pntd.0002657

50. Bhattacharyya T, Bowes DE, El-Safi S, Sundar S, Falconar AK, Singh OP, et al. Significantly lower anti-Leishmania IgG responses in Sudanese versus Indian visceral leishmaniasis. PLoS Negl Trop Dis (2014) 8(2):e2675. doi:10.1371/journal.pntd.0002675

51. El-On J. Current status and perspectives of the immunotherapy of leishmaniasis. Isr Med Assoc J (2009) 11:623-8.

52. Sundar S, Rosenkaimer F, Lesser ML, Murray HW. Immunochemotherapy for a systemic intracellular infection: accelerated response using interferon-gamma in visceral leishmaniasis. J Infect Dis (1995) 171:992-6. doi:10.1093/infdis/171. 4.992

53. Badaro R, Falcoff E, Badaro FS, Carvalho EM, Pedral-Sampaio D, Barral A, et al. Treatment of visceral leishmaniasis with pentavalent antimony and interferon gamma. N Engl J Med (1990) 322:16-21. doi:10.1056/NEJM199001043220104

54. Almeida RP, Brito J, Machado PL, De Jesus AR, Schriefer A, Guimarães LH, et al. Successful treatment of refractory cutaneous leishmaniasis with GM-CSF and antimonials. Am J Trop Med Hyg (2005) 73:79-81.

55. Mayrink W, Botelho AC, Magalhães PA, Batista SM, Lima Ade O, Genaro O, et al. Immunotherapy, immunochemotherapy, and chemotherapy for American cutaneous leishmaniasis treatment. Rev Soc Bras Med Trop (2006) 39:14-21. doi:10.1590/S0037-86822006000100003

56. Badaro R, Lobo I, Munos A, Netto EM, Modabber F, Campos-Neto A, et al. Immunotherapy for drug-refractory mucosal leishmaniasis. J Infect Dis (2006) 194:1151-9. doi:10.1086/507708

57. Machado-Pinto J, Pinto J, da Costa CA, Genaro O, Marques MJ, Modabber F, et al. Immunochemotherapy for cutaneous leishmaniasis: a controlled trial using killed Leishmania (Leishmania) amazonensis vaccine plus antimonial. Int J Dermatol (2002) 41:73-8. doi:10.1046/j.1365-4362.2002.01336.x

58. García Bustos MF, Barrio AB, Parodi Ramoneda CM, Ramos F, Mora MC, Convit J, et al. Immunological correlates of cure in the first American cutaneous leishmaniasis patient treated by immunotherapy in Argentina. A case report. Invest Clin (2013) 52:365-75. 
59. Arevalo I, Tulliano G, Quispe A, Spaeth G, Matlashewski G, Llanos-Cuentas A, et al. Role of imiquimod and parenteral meglumine antimoniate in the initial treatment of cutaneous leishmaniasis. Clin Infect Dis (2007) 44:1549-54. doi:10.1086/518172

60. Squires KE, Rosenkaimer F, Sherwood JA, Forni AL, Were JB, Murray HW. Immunochemotherapy for visceral leishmaniasis: a controlled pilot trial of antimony versus antimony plus interferon-gamma. Am J Trop Med Hyg (1993) 48:666-9.

61. Musa AM, Khalil EA, Mahgoub FA, Elgawi SH, Modabber F, Elkadaru AE, et al. Immunochemotherapy of persistent post-kala-azar dermal leishmaniasis: a novel approach to treatment. Trans R Soc Trop Med Hyg (2008) 102:58-63. doi:10.1016/j.trstmh.2007.08.006

62. Firooz A, Khamesipour A, Ghoorchi MH, Nassiri-Kashani M, Eskandari SE, Khatami A, et al. Imiquimod in combination with meglumine antimoniate for cutaneous leishmaniasis: a randomized assessor-blind controlled trial. Arch Dermatol (2006) 142:1575-9. doi:10.1001/archderm.142.12.1575

63. Sergiev VP, Shuikina EE, Kuznetsov VP, Beliaev DL, Fediainova IE, Norbadalov MT, et al. The use of leukinferon in treating zoonotic cutaneous leishmaniasis. 2. Patient treatment. Med Parazitol (Mosk) (1993) (1):42-3.

64. Convit J, Ulrich M, Zerpa O, Borges R, Aranzazu N, Valera M, et al. Immunotherapy of American cutaneous leishmaniasis in Venezuela during the period 1990-99. Trans R Soc Trop Med Hyg (2003) 97:469-72. doi:10.1016/ S0035-9203(03)90093-9

65. O’Daly JA, Spinetti HM, Gleason J, Rodríguez MB. Clinical and immunological analysis of cutaneous leishmaniasis before and after different treatments. J Parasitol Res (2013) 2013:657016. doi:10.1155/2013/657016

66. Convit J, Ulrich M, Polegre MA, Avila A, Rodríguez N, Mazzedo MI, et al. Therapy of Venezuelan patients with severe mucocutaneous or early lesions of diffuse cutaneous leishmaniasis with a vaccine containing pasteurized Leishmania promastigotes and bacillus Calmette-Guerin: preliminary report. Mem Inst Oswaldo Cruz (2004) 99:57-62. doi:10.1590/S007402762004000100010

67. Laskay T, van Zandbergen G, Solbach W. Neutrophil granulocytes as host cells and transport vehicles for intracellular pathogens: apoptosis as infectionpromoting factor. Immunobiology (2008) 213:183-91. doi:10.1016/j.imbio. 2007.11.010

68. Aga E, Katschinski DM, van Zandbergen G, Laufs H, Hansen B, Müller K, et al. Inhibition of the spontaneous apoptosis of neutrophil granulocytes by the intracellular parasite Leishmania major. J Immunol (2002) 169:898-905. doi:10.4049/jimmunol.169.2.898

69. Laufs H, Müller K, Fleischer J, Reiling N, Jahnke N, Jensenius JC, et al. Intracellular survival of Leishmania major in neutrophil granulocytes after uptake in the absence of heat-labile serum factors. Infect Immun (2002) 70:826-35. doi:10.1128/IAI.70.2.826-835.2002

70. Saha P, Bhattacharjee S, Sarkar A, Manna A, Majumder S, Chatterjee M. Berberine chloride mediates its anti-leishmanial activity via differential regulation of the mitogen activated protein kinase pathway in macrophages. PLoS One (2011) 6:e18467. doi:10.1371/journal.pone.0018467

71. Muniz-Junqueira MI, de Paula-Coelho VN. Meglumine antimonate directly increases phagocytosis, superoxide anion and TNF-alpha production, but only via TNF-alpha it indirectly increases nitric oxide production by phagocytes of healthy individuals, in vitro. Int Immunopharmacol (2008) 8:1633-8. doi:10.1016/j.intimp.2008.07.011

72. Shadab M, Ali N. Evasion of host defence by Leishmania donovani: subversion of signaling pathways. Mol Biol Int (2011) 2011:343961. doi:10.4061/2011/ 343961

73. Oghumu S, Gupta G, Snider HM, Varikuti S, Terrazas CA, Papenfuss TL, et al. STAT4 is critical for immunity but not for antileishmanial activity of antimonials in experimental visceral leishmaniasis. Eur J Immunol (2013) 44(2):450-9. doi:10.1002/eji.201343477

74. Nylén S, Maurya R, Eidsmo L, Manandhar KD, Sundar S, Sacks D. Splenic accumulation of IL-10 mRNA in T cells distinct from CD4+CD25+ (Foxp3) regulatory T cells in human visceral leishmaniasis. J Exp Med (2007) 204:805-17. doi:10.1084/jem.20061141

75. Peters N, Sacks D. Immune privilege in sites of chronic infection: Leishmania and regulatory T cells. Immunol Rev (2006) 213:159-79. doi:10.1111/j.1600065X.2006.00432.x

76. Olivier M, Gregory DJ, Forget G. Subversion mechanisms by which Leishmania parasites can escape the host immune response: a signaling point of view. Clin Microbiol Rev (2005) 18:293-305. doi:10.1128/CMR.18.2.293-305. 2005

77. Brandonisio O, Spinelli R, Pepe M. Dendritic cells in Leishmania infection. Microbes Infect (2004) 6:1402-9. doi:10.1016/j.micinf.2004.10.004

78. Joshi T, Rodriguez S, Perovic V, Cockburn IA, Stager S. B7-H1 blockade increases survival of dysfunctional CD8 (+) T cells and confers protection against Leishmania donovani infections. PLoS Pathog (2009) 5(5):e1000431. doi:10.1371/journal.ppat.1000431

79. Murray HW, Lu CM, Brooks EB, Fichtl RE, DeVecchio JL, Heinzel FP. Modulation of T-cell costimulation as immunotherapy or immunochemotherapy in experimental visceral leishmaniasis. Infect Immun (2003) 71:6453-62. doi:10.1128/IAI.71.11.6453-6462.2003

80. Murray HW, Moreira AL, Lu CM, DeVecchio JL, Matsuhashi M, Ma X, et al. Determinants of response to interleukin-10 receptor blockade immunotherapy in experimental visceral leishmaniasis. J Infect Dis (2003) 188:458-64. doi: $10.1086 / 376510$

81. Sundar S, Murray HW. Effect of treatment with interferon-gamma alone in visceral leishmaniasis. J Infect Dis (1995) 172:1627-9. doi:10.1093/infdis/172. 6.1627

82. Murray HW, Flanders KC, Donaldson DD, Sypek JP, Gotwals PJ, Liu J, et al. Antagonizing deactivating cytokines to enhance host defense and chemotherapy in experimental visceral leishmaniasis. Infect Immun (2005) 73:3903-11. doi:10.1128/IAI.73.7.3903-3911.2005

83. Moore KW, de Waal Malefyt R, Coffman RL, O'Garra A. Interleukin-10 and the interleukin-10 receptor. Annu Rev Immunol (2001) 19:683-765. doi:10.1146/annurev.immunol.19.1.683

84. Murphy ML, Wille U, Villegas EN, Hunter CA, Farrell JP. IL-10 mediates susceptibility to Leishmania donovani infection. Eur J Immunol (2001) 31:2848-56. doi:10.1002/1521-4141(2001010)31:10<2848::AID-IMMU2848>3.0.CO;2-T

85. Murray HW. Interleukin 10 receptor blockade - pentavalent antimony treatment in experimental visceral leishmaniasis. Acta Trop (2005) 93:295-301. doi:10.1016/j.actatropica.2004.11.008

86. Murray HW, Brooks EB, DeVecchio JL, Heinzel FP. Immunoenhancement combined with amphotericin B as treatment for experimental visceral leishmaniasis. Antimicrob Agents Chemother (2003) 47:2513-7. doi:10.1128/AAC.47.8. 2513-2517.2003

87. Nylen S, Sacks D. Interleukin-10 and the pathogenesis of human visceral leishmaniasis. Trends Immunol (2007) 28:378-84. doi:10.1016/j.it.2007.07.004

88. Ansari NA, Kumar R, Gautam S, Nylén S, Singh OP, Sundar S, et al. IL-27 and IL-21 are associated with T cell IL-10 responses in human visceral leishmaniasis. J Immunol (2011) 186:3977-85. doi:10.4049/jimmunol.1003588

89. Gautam S, Kumar R, Maurya R, Nylén S, Ansari N, Rai M, et al. IL-10 neutralization promotes parasite clearance in splenic aspirate cells from patients with visceral leishmaniasis. J Infect Dis (2011) 204:1134-7. doi:10. 1093/infdis/jir461

90. Anderson CF, Oukka M, Kuchroo VJ, Sacks D. CD4(+)CD25(-)Foxp3(-) Th1 cells are the source of IL-10-mediated immune suppression in chronic cutaneous leishmaniasis. J Exp Med (2007) 204:285-97. doi:10.1084/jem. 20061886

91. Belkaid Y, Piccirillo CA, Mendez S, Shevach EM, Sacks DL. CD4+CD25+ regulatory $\mathrm{T}$ cells control Leishmania major persistence and immunity. Nature (2002) 420:502-7. doi:10.1038/nature01152

92. Holaday BJ. Role of CD8+ T cells in endogenous interleukin-10 secretion associated with visceral leishmaniasis. Mem Inst Oswaldo Cruz (2000) 95:217-20. doi:10.1590/S0074-02762000000200013

93. Singh OP, Gidwani K, Kumar R, Nylén S, Jones SL, Boelaert M, et al. Reassessment of immune correlates in human visceral leishmaniasis as defined by cytokine release in whole blood. Clin Vaccine Immunol (2012) 19:961-6. doi:10.1128/CVI.00143-12

94. Singh OP, Sundar S. Whole blood assay and visceral leishmaniasis: challenges and promises. Immunobiology (2014) 219:323-8. doi:10.1016/j.imbio.2014.01 005

95. Carvalho EM, Bacellar O, Brownell C, Regis T, Coffman RL, Reed SG. Restoration of IFN-gamma production and lymphocyte proliferation in visceral leishmaniasis. J Immunol (1994) 152:5949-56.

96. Moll H. Dendritic cells and host resistance to infection. Cell Microbiol (2003) 5(8):493-500. doi:10.1046/j.1462-5822.2003.00291.x

97. Colmenares M, Corbi AL, Turco SJ, Rivas L. The dendritic cell receptor DC-SIGN discriminates among species and life cycle forms of 
Leishmania. J Immunol (2004) 172:1186-90. doi:10.4049/jimmunol.172.2. 1186

98. Ghosh M, Pal C, Ray M, Maitra S, Mandal L, Bandyopadhyay S. Dendritic cell-based immunotherapy combined with antimony-based chemotherapy cures established murine visceral leishmaniasis. J Immunol (2003) 170:5625-9. doi:10.4049/jimmunol.170.11.5625

99. Meheus F, Balasegaram M, Olliaro P, Sundar S, Rijal S, Faiz MA, et al. Cost-effectiveness analysis of combination therapies for visceral leishmaniasis in the Indian subcontinent. PLoS Negl Trop Dis (2010) 4(9):e818. doi:10.1371/journal.pntd.0000818

100. Bryceson A. A policy for leishmaniasis with respect to the prevention and control of drug resistance. Trop Med Int Health (2001) 6:928-34. doi:10.1046/j. 1365-3156.2001.00795.x

101. Davis AJ, Murray HW, Handman E. Drugs against leishmaniasis: a synergy of technology and partnerships. Trends Parasitol (2004) 20:73-6. doi:10.1016/j. pt.2003.11.006

102. Smith AC, Yardley V, Rhodes J, Croft SL. Activity of the novel immunomodulatory compound tucaresol against experimental visceral leishmaniasis. Antimicrob Agents Chemother (2000) 44:1494-8. doi:10.1128/AAC.44.6.1494-1498. 2000
103. Sundar S, Chatterjee M. Visceral leishmaniasis - current therapeutic modalities. Indian J Med Res (2006) 123:345-52.

Conflict of Interest Statement: The authors declare that the research was conducted in the absence of any commercial or financial relationships that could be construed as a potential conflict of interest.

Received: 03 January 2014; accepted: 07 June 2014; published online: 26 June 2014. Citation: Singh OP and Sundar S (2014) Immunotherapy and targeted therapies in treatment of visceral leishmaniasis: current status and future prospects. Front. Immunol. 5:296. doi: 10.3389/fimmu.2014.00296

This article was submitted to Immunotherapies and Vaccines, a section of the journal Frontiers in Immunology.

Copyright (c) 2014 Singh and Sundar. This is an open-access article distributed under the terms of the Creative Commons Attribution License (CC BY). The use, distribution or reproduction in other forums is permitted, provided the original author (s) or licensor are credited and that the original publication in this journal is cited, in accordance with accepted academic practice. No use, distribution or reproduction is permitted which does not comply with these terms. 